\title{
Measuring attitudes in the self-employment intention model: methodological considerations
}

\author{
Josipa Mijoč $^{1, \dagger}$, Marina Stanić ${ }^{1}$ and Jasna Horvat ${ }^{1}$ \\ ${ }^{1}$ Faculty of Economics in Osijek, University of Josip Juraj Strossmayer in Osijek, Gajev \\ $\operatorname{trg}$ 7, 31000 Osijek, Croatia \\ E-mail: 〈\{jmijoc, marina,jasna\}@efos.hr $\rangle$
}

\begin{abstract}
The paper is based on a statistical model, the construction of which requires determining the independent variables. To determine the predictive ability of different approaches to measuring independent variables, the paper provides an overview of theoretical and research approaches to the research problem. The purpose of the study is to analyze the predictive power of instruments measuring attitudes toward selfemployment as one of the most significant predictors of a career choice according to the theory of planned behavior. The paper juxtaposes two various measurement approaches in assessing attitudes toward self-employment. The first approach is based on behavioral beliefs that produce favorable or unfavorable attitudes toward a self-employed career and considers two opposing options: pursuing a self-employed career or accepting a job position (working for an employer). In this context, developing a measurement construct is a multistep process that requires testing psychometric characteristics of proposed measures based on predefined theoretical and empirical dimensions. The second approach incorporates aggregate measures of attitude toward self-employment in which the predictor variable is assessed from only one perspective, without taking into account other career options.

Through the means of multiple regression analysis, the paper details a comparison of both measurement approaches and their performance in explaining the dependent variable (selfemployment intention). The predictive power of the model is defined as a criterion for selecting a measurement approach that can serve as a methodological framework for prospective studies focused on investigating attitudes toward certain behavior.
\end{abstract}

Keywords: prediction model, regression coefficient, measurement construct, attitude, selfemployment intention

Received: October 25, 2016; accepted: December 14, 2016; available online: December 30, 2016

DOI: $10.17535 /$ crorr. 2016.0023

\footnotetext{
$\dagger$ Corresponding author 


\section{Introduction}

Intentions can be described as a state of mind that help the individual in dedicating attention, gaining experience and focusing actions towards specific behavior or object (Bird, 1988). Ajzen (1991) argues that intentions reflect the motivational factors that influence behavior. Overall, researchers have reached agreement that intentions represent the best single predictor of planned behavior (Ajzen, 1991, 2001, Bagozzi et al., 1989, Fishbein and Ajzen, 1975, Souitaris et al., 2007), and they are especially suitable for researching behaviors that are rare, difficult to observe or include unforeseen time lags. Entrepreneurship (selfemployment) is a typical example of planned, intentional behavior (Bird, 1988, MacMillan and Katz 1992, Krueger and Brazeal, 1994, Katz and Gartner, 1988, Liñán, 2004, Kuehn and Smith, 2008, Krueger et al., 2000). Krueger and Carsrud (1993) point out that the creation of a new company requires time, involves considerable planning and a high level of cognitive abilities, and therefore can be observed as planned behavior, for which intention models are applicable.

Self-employment is one of the possible career choices of individuals. Today's students are tomorrow's prospective (self)employed persons, and an examination of their intentions to choose self-employment as a career is important to creators of both educational and economic policies. In addition, choosing self-employment as a career is also an attractive choice for unemployed young people, especially if it implies exploiting a business opportunity.

Most of the study in the field of self-employment intentions is focused on theory development by looking at antecedents of intention and identifying mediating and moderating variables. However, in addition to theoretical concepts and applied models, methodological decisions and the way variables are operationalized also significantly influences the final results in terms of model structure and predictive power. Therefore, this study is focused on methodology issues related to measurement of one of the most significant antecedents of self-employment intention-personal attitudes toward a self-employed career. The paper juxtaposes two common approaches in measuring attitudes of younger age groups towards self-employment as a career choice and demonstrates how a different understanding of attitudes towards a specific behavior, and thus also towards selfemployment, affects the methodological approach to measuring them. Regression analysis is employed for the purpose of developing and comparing two models that differ in the way the attitude variable is operationalized.

\section{Previous research}

The application of intentions in the domain of entrepreneurship (self-employment) research started soon after Ajzen (1991) revised his theory of planned behavior (TPB). The theory of planned behavior is probably the most commonly applied 
theoretical framework for studying self-employment intentions since starting a new business venture is considered both intentional behavior (Bird, 1988, Krueger and Carsrud, 1993) and planned behavior (Autio et al., 1997). Krueger et al. (2000) points out that, prior to the TPB, research in entrepreneurship mainly comprised less robust and predictive approaches, using personality traits, demographic characteristics, situational factors or approaches that observed attitudes (Krueger and Carsrud 1993, Carsrud et al., 1993). Kolvereid and Isaksen (2006) argue that intentions for self-employment determine the later decision to pursue self-employment as a career choice, which provides support for the use of research models in which intentions are the best predictors of this specific behavior.

The theory of planned behavior incorporates three elements: an individual's attitude towards specific behavior (attitude), an individual's perception of expectations (opinions) of other persons towards the selected behavior (subjective norm) and an individual's personal beliefs about their own control over the planned behavior (perceived behavioral control).

A high correlation between the TPB and intentions for self-employment was reported by Solesvik et al. (2012) and Liñán and Chen (2009), who, by modelling structural equations, have shown that TPB explains $55 \%$ of the variance of intentions for self-employment. On a sample of 143 Norwegian students, Kolvereid (1996b) has demonstrated that attitudes, subjective norm and perceived behavioral control affect the intentions for self-employment, while demographic characteristics of the respondents (gender, self-employed parents, experience in self-employment) affect them only indirectly. Krueger et al. (2000) have pointed out the connection of perceived behavioral control and attitudes with entrepreneurial intentions, but have not found a statistically important correlation between subjective norms and intentions. Researchers have shown that attitudes towards self-employment and perceived behavioral control have significant predictive power in measuring intentions (Krueger et al., 2000, Liñán and Chen, 2009, Autio et al., 2001).

When looking at the meaning of the TPB from the aspect of self-employment, the expectation is that the formation of self-employment intentions will be affected mostly by beliefs and attitudes towards self-employment. Ajzen (1991) defines attitudes as beliefs and perceptions with respect to personal desirability of performing behaviors, which are in turn connected to expectations of how outcomes resulting from behavior will affect the individual. In other words, individuals create their attitudes towards observed behavior based on favorable (positive) or unfavorable (negative) assessment of behavior. Based on the previous studies, personal attitudes toward a self-employed career are one of the strongest predictors of self-employment intention. In other words, in many studies, attitudes contribute to the model exhibiting the highest percentage of dependent variable explanation (Basu and Virick, 2008, Gird and Bagaraim, 2008, Kruger et al., 2000, 
Leffel, 2008, Liñán and Chen, 2009, Solvesnik, 2011, Solvesnik et al., 2012). Based on previous research results and on the strong foundation in the theoretical framework, this study hypothesizes the following:

H1: Attitudes towards self-employment retain the highest predictive ability of a model in which elements of the TPB are independent variables, regardless of the way attitudes are measured.

As previously stated, attitudes reflect an individual's positive or negative assessment of a self-employed career as opposed to working for someone. An individual's more positive perception towards the outcome of starting a career as self-employed person leads to more positive attitude towards such behavior, and therefore intensifies self-employment intention. Accordingly, attitudes can be approached from two different perspectives: (1) evaluating attitudes toward a selfemployed career as opposed to being employed in an organization, and (2) assessing attitudes toward self-employment career directly, without considering other options, using a simple measurement construct with the Likert-type scale. Both approaches have been applied in previous research interchangeably, yet the choice of a measurement approach has implications for the predictive power of predictors as well as the entire model. That being said, the second hypothesis is set as following:

$\mathrm{H} 2$ : Selection of a different approach in measuring attitudes towards selfemployment has a significantly different predictive ability in explaining selfemployment intentions.

\section{Methodology}

The research focuses on second-year graduate students at the Faculty of Economics, Josip Juraj Strossmayer University in Osijek. Data was collection through a highly structured questionnaire in June 2012 using a "paper and pen" method with the examiner present. Students were asked to participate voluntary and anonymously in the study.

\subsection{Sample and data collection}

Students represent the most common respondents in research when examining self-employment intentions (Tkachev and Kolvereid, 1999, Jaén et al., 2010, Audet, 2004, Solesvik et al., 2012, Wu and Wu, 2008, Autio et al., 2001, Zhao et al., 2005, Krueger et al., 2000, Leffel, 2008, Kolvereid, 1996b, Liñán and Chen, 2009). Second-year graduate students are the target group of this research as they are about to finish their studies and face the decision as to choice of career. The expectation is that students studying graduate program will have ample time and 
energy to plan future business ventures (Audet, 2004). The advantage of using samples of students is the mutual homogeneity of the respondents in terms of age and qualifications (Liñán and Chen, 2009). The questionnaire was filled out by a total of 453 students, of which 428 were further analyzed.

\begin{tabular}{|c|c|c|c|c|c|}
\hline & $\mathrm{n}$ & $\%$ & & $\mathrm{n}$ & $\%$ \\
\hline \multicolumn{3}{|l|}{ Gender } & \multicolumn{3}{|c|}{ Founded a company } \\
\hline Male & 137 & 32.0 & Yes & 6 & 1.4 \\
\hline Female & 291 & 68.0 & No & 413 & 98.6 \\
\hline \multicolumn{3}{|l|}{ Field of study } & \multicolumn{3}{|c|}{ Self-employment of parents } \\
\hline $\begin{array}{l}\text { Financial } \\
\text { management }\end{array}$ & 141 & 33.0 & Yes & 126 & 29.4 \\
\hline Marketing & 54 & 12.6 & No & 302 & 70.6 \\
\hline Management & 104 & 24.4 & \multicolumn{3}{|c|}{ Work in family business } \\
\hline Entrepreneurship & 72 & 16.9 & Yes & 66 & 52.8 \\
\hline Business informatics & 56 & 13.1 & No & 59 & $\begin{array}{l}47 . \\
2\end{array}$ \\
\hline
\end{tabular}

Table 1: Sample description

Descriptive analysis showed that $32.0 \%$ of students in the sample are male, their average age is 23.8 years, and the majority are full-time students (93.6\%). Respondents have on average spent 4.6 years at the faculty, which shows that these students regularly fulfil their study obligations. On average, students have achieved an average grade of 3.49 at the undergraduate level, and 3.79 at the graduate level.

In terms of exposure to self-employment, $29.4 \%$ of respondents have had the opportunity of encountering self-employment seeing one of both of their parents managing a family business, and as many as $52.8 \%$ worked in such family business. However, the respondents generally had no previous experience in running their own businesses, as only $1.4 \%$ of them stated that they were self-employed.

\subsection{Measures}

The questionnaire was developed by modifying certain theoretical and empirical findings from previous studies (Kolvereid, 1996b, Helmreich and Spence, 1978, Zhao et al., 2005, Krueger et al., 2000, Liñán and Chen, 2009) in terms of dependent and independent variables, with the aim of increasing the reliability and validity of the questionnaire and research. 


\subsubsection{Dependent variable}

Self-employment intentions is the dependent variable. There are five statements about intentions on choosing self-employment as a career. Since different measurement scales (Likert scale and probability of event) were used, the original values of these statements were standardized (z-score) before creating the measured construct. Following the standardization process, the same statements were used to calculate the average value, which ultimately represents a new variable -selfemployment intentions.

The coefficient of reliability for the construct is extremely high (0.895) and the five items are considered adequate for measuring self-employment intentions. All the items exceed the recommended limit of acceptability in terms of correlation of items towards the overall result, and the values of correlation between the items exceed a correlation of 0.5. Exploratory factor analysis was carried out to check the one-dimensionality of the construct. The size of the observed sample is sufficient for implementing factor analysis. In addition to the sample size, factor analysis is justified as the values in the correlation matrix exceed 0.5 , the value of the Bartlett's test for statistical significance of correlation matrix is $\chi^{2}=$ 1194.019 with 10 degrees of freedom and a level of significance $\mathrm{p}<0.001$. KMO test results are also satisfactory, since the value is 0.869 . All the manifest variables with inherent values greater than 1 were formed into a single component with a total variance explanation of $70.6 \%$. Consequently, the measured construct of selfemployment intention is considered reliable and one-dimensional, and the proposed factors can further be used as a manifest variable (dependent variable), which is constructed as the average score of the mentioned standardized variables (SEFL_INT). When checking the normal distribution of data of the new variable, not a single standardized value greater than \pm 3 standard deviations was found, where the measure of asymmetry (skewness $=-0.019$ ) and measure of curvature (kurtosis $=-0.535$ ) point to a normal distribution of the data series. Checking for outliers indicated no outlier issues for the data.

\subsubsection{Independent variables}

The predictors of intentions of future behavior are: attitudes towards specific behavior, subjective norm and perceived behavioral control. The instrument developed by Kolvereid (1996b) was used for measuring the subjective norm construct. The construct is considered reliable due to the value of the coefficient of reliability $(0.860)$, high correlation between items $(\overline{\mathrm{x}}=0.671)$ and correlation of items towards the measured construct $(\overline{\mathrm{x}}=0.732)$. The conducted factor analysis classified the items into one factor with a variance of $78.16 \%(\mathbf{S N})$. Perceived behavioral control relates to an individual's perception of a simple or fraught with difficulties in self-employment as a career. Based on the psychometric 
analysis of the measured construct, its internal consistency was determined (standardized Cronbach's alpha is 0.705 , average correlation between items is 0.444 , and the average correlation towards the measured construct is 0.524$)$. The factor analysis indicates the existence of one factor that explains $62.93 \%$ of the variance $(\mathbf{P C B})$. The authors will devote greater attention to measuring attitudes as the most important independent variable in the remainder of the paper.

\subsubsection{Attitudes towards self-employment}

Measurement of attitudes towards self-employment was observed by the authors to flow in two directions. Some measuring instruments have been developed based on Ajzen's (1991) proposal of measuring and observing the strength of belief towards an attitude where there are two opposing choices (e.g. choice of selfemployment as a career and working for someone else as a career). The second approach relates to direct measurement of attitudes, and in that case attitudes towards self-employment are usually measured unconditionally (without statements about another career choice).

\section{First approach - indirect measurement of attitudes}

Attitudes towards self-employment are adapted to theory (Kolvereid, 1999b), which relies on the strength of belief (Ajzen, 1991), where evaluation of a career path is measured from answers that view positively or negatively self-employment as a career as opposed to being employed in an organization as a career. In his study, Kolvereid posed two questions to graduated students (1996a). The first question is similar to question NS1 in this study, where respondents identified their career choice on a five-level Likert scale $(1$ - employed by someone, 5 - selfemployed). The aim of the second open-ended question is to shed light on the reasons for the previous career choice: what are the main reasons you chose one career over the other. Eventually, Kolvereid (1996a) proposed a classification that contained 11 different dimensions (factors) in which 39 reasons for selecting a particular career were classified. In the proposed classification, there were five categories relating to working for an employer as a career (security, work load, social environment, avoiding responsibility, career), and six that related to selfemployment as a career (economic opportunity, challenge, autonomy, authority, self-realization, participation in the whole process). After retesting the model, Kolvereid (1996b) in his later paper proposed a classification containing 11 categories and 33 reasons (items, job characteristics), which students either consider or do not consider when choosing a career.

In this study, respondents were asked to use the five-point Likert scale to answer to what extent they considered each of the proposed 33 statements (job characteristics) when choosing a career ( 1 - Will not consider, 5 - Will consider). 
Exploratory factor analysis was conducted to check the theoretical justification of using all the variables. The high value of the KMO test (0.883) and statistically significant Bartlett's test $\left(x^{2}=6022.606, \mathrm{df}=406, \mathrm{p}<0.001\right)$ justify conducting factor analysis. Factor analysis that included all 33 items did not show a satisfactory classification of factors. Orthogonal Varimax factor rotation using Kaiser's criterion was carried out, and ultimately, factor analysis according to which items were classified into 11 factors, 4 items were excluded (ST4, 17, 24 and 25). Factor analysis of the proposed 11 factors explains $76.48 \%$ of the total variance on the measured construct (Table 2).

\begin{tabular}{|c|c|c|c|}
\hline Factors $^{1}$ & $\begin{array}{c}\text { Cro- } \\
\text { nbach } \\
\alpha\end{array}$ & $\begin{array}{c}\text { Inter- } \\
\text { item } \\
\text { correlati } \\
\text { on }(\overline{\mathrm{x}}) \\
\end{array}$ & $\begin{array}{c}\text { Item- } \\
\text { total } \\
\text { correlat } \\
\text { ion }(\overline{\mathrm{x}})\end{array}$ \\
\hline Security & 0.941 & 0.889 & 0.889 \\
\hline $\begin{array}{l}\text { Work } \\
\text { load }\end{array}$ & 0.731 & 0.406 & 0.524 \\
\hline $\begin{array}{l}\text { Social } \\
\text { enviro- } \\
\text { nment }\end{array}$ & 0.720 & 0.565 & 0.565 \\
\hline $\begin{array}{l}\text { Avoiding } \\
\text { response- } \\
\text { bility }\end{array}$ & 0.854 & 0.645 & 0.712 \\
\hline Career & \begin{tabular}{|l|}
0.849 \\
\end{tabular} & 0.737 & 0.737 \\
\hline
\end{tabular}

1 - attitude towards being employed

\begin{tabular}{|l|c|c|c|}
\hline Factors $^{2}$ & $\begin{array}{c}\text { Cro- } \\
\text { nbac } \\
\mathrm{h} \alpha\end{array}$ & $\begin{array}{l}\text { Inter- } \\
\text { item } \\
\text { correla- } \\
\text { tion }(\overline{\mathrm{x}})\end{array}$ & $\begin{array}{l}\text { Item- } \\
\text { total } \\
\text { correla- } \\
\text { tion }(\overline{\mathrm{x}})\end{array}$ \\
\hline $\begin{array}{l}\text { Economic } \\
\text { opportu- } \\
\text { nity }\end{array}$ & 0.689 & 0.424 & 0.505 \\
\hline Challenge & 0.874 & 0.638 & 0.734 \\
\hline $\begin{array}{l}\text { Autono- } \\
\text { my }\end{array}$ & 0.824 & 0.701 & 0.701 \\
\hline $\begin{array}{l}\text { Authority } \\
\text { Authe }\end{array}$ & 0.761 & 0.617 & 0.617 \\
\hline $\begin{array}{l}\text { Self- } \\
\text { realizati- } \\
\text { on }\end{array}$ & 0.776 & 0.538 & 0.614 \\
\hline $\begin{array}{l}\text { Participa- } \\
\text { tion in } \\
\text { the whole } \\
\text { process }\end{array}$ & 0.705 & 0.547 & 0.547 \\
\hline- attitıde & & & \\
\hline
\end{tabular}
in an organization

2 - attitude towards self-employment

Table 2: Psychometric characteristics for 11 constructs in measuring attitudes towards the selection of future professional career

The conclusion for all 11 factors is that they have sufficient internal consistency. The Cronbach alpha coefficient of reliability is acceptable for all factors, although there is room for improvement of the economic opportunity factor (0.689). The average correlation between items and average correlation between items and the measured construct are acceptable for all constructs. 
Based on the results of factor analysis and reliability analysis for the proposed 11 factors, 11 new variables were calculated, and created using the average scores of items from each of the factors. The results of the factors show that respondents awarded the lowest average score to the avoiding responsibility factor (2.26), and the highest to the career factor (4.47). Then, two new variables were created from these 11 variables, one of which was calculated as the average of the first five factors (attitude towards employment in an organization) and the other as the average of the remaining six variables (attitude towards self-employment). Finally, calculation of differences between the created variables resulted in a new variable that measures attitude towards choosing a career (ATT_1), where higher values indicate a preference for self-employment as a career, whereas lower values indicate a preference for working for someone as a career.

\section{Second approach - direct measurement of attitudes (aggregated scale)}

However, the previous approach to measuring attitudes has been criticized by Liñán and Chen (2009), who suggest that measurement of attitudes should be based on an aggregated measurement scale. Adapting the research of Liñán and Chen (2009) and Krueger (1993), respondents were offered three statements to rate on a five-level Likert scale (1 - I completely disagree, 5 - I completely agree), the idea of having my own business is very attractive to me, working in my own company would be a personal satisfaction and I cannot imagine working for someone else. These statements focused exclusively on "positive" behavior of the research, which is towards self-employment as a career. The proposed measured construct (ATT_2) has satisfactory internal reliability since the Cronbach alpha is 0.719 , the average correlation between items is 0.458 , and the average correlation to the measured construct is 0.551 . As expected, all the items are classified into one factor with the explanation of variance equivalent to $65.16 \%$.

\section{Results and discussion}

After adjusting the variables, the results of multiple regression analysis were recorded. Two regression models were compared on the basis of TPB as independent variables, using different approaches of measuring attitudes towards self-employment. A descriptive overview of the new variables is available in Table 3 . The standardized values of the variables are within the interval of \pm 3 standard deviations $s^{\ddagger}$. The Q-Q plot of normality for data shows no existence of serious outliers in the series, but only several moderate outliers were observed, which is common for a large sample. Skewness and kurtosis are within acceptable limits.

\footnotetext{
¥Variable ATT_XP has two standardized values that are greater than 3 , but less than 4 . The respondents with these values are not excluded from further analysis.
} 


\begin{tabular}{|l|c|c|c|c|c|}
\hline Constructs & $\mathrm{n}$ & $\begin{array}{c}\text { Arithmetic } \\
\text { mean }\end{array}$ & $\begin{array}{c}\text { Standard } \\
\text { deviation }\end{array}$ & Skewness & Kurtosis \\
\hline ATT_1 & 425 & .50 & .56607 & .010 & .758 \\
\hline ATT_2 & 427 & 3.28 & 0.84164 & -.552 & .065 \\
\hline SN & 427 & .75 & 3.50226 & .393 & .677 \\
\hline PBC & 427 & 3.16 & .72612 & .031 & .051 \\
\hline
\end{tabular}

Table 3: Descriptive statistics for TPB constructs

The Pearson correlation coefficient indicates a positive correlation between the observed variables of the TPB and self-employment intentions (Table 4). When comparing the two approaches to measuring attitudes and their association with the dependent variable, it becomes evident that ATT_2 correlates more strongly towards intentions $(\mathrm{r}=0.739)$ compared to ATT_1 $(\mathrm{r}=335)$. The measured constructs SN and PBC are also strongly associated with the dependent variable. Correlations between the independent variables are not high, which does not indicate the existence of multicollinearity among the observed variables.

\begin{tabular}{|c|c|c|c|c|c|c|}
\hline & & (1) & (2) & (3) & (4) & $(5)$ \\
\hline \multirow{3}{*}{ (1) SELF_INT } & $\mathrm{r}$ & \multirow[t]{3}{*}{1} & \multirow[t]{3}{*}{ 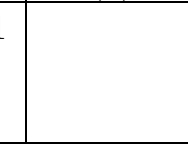 } & & & \\
\hline & $\mathrm{p}$ & & & & & \\
\hline & $\mathrm{n}$ & & & & & \\
\hline \multirow{3}{*}{ (2) $\mathrm{ATT}_{-} 1$} & $\mathrm{r}$ & $.335^{* * *}$ & \multirow[t]{3}{*}{1} & & & \\
\hline & $\mathrm{p}$ & .000 & & & & \\
\hline & $\mathrm{n}$ & 425 & & & & \\
\hline \multirow{3}{*}{ (3) ATT_2 } & $\mathrm{r}$ & $.739^{* *}$ & $.321^{* * *}$ & \multirow[t]{3}{*}{1} & & \\
\hline & $\mathrm{p}$ & .000 & .000 & & & \\
\hline & $\mathrm{n}$ & 427 & 425 & & & \\
\hline \multirow{3}{*}{ (4) $\mathrm{SN}$} & $\mathrm{r}$ & $.533^{* * *}$ & $.224^{* * *}$ & \multirow{3}{*}{$\begin{array}{r}.529^{* * *} \\
.000 \\
427\end{array}$} & \multirow[t]{3}{*}{1} & \\
\hline & $\mathrm{p}$ & .000 & .000 & & & \\
\hline & $\mathrm{n}$ & 427 & 425 & & & \\
\hline \multirow{3}{*}{ (5) $\mathrm{PBC}$} & $\mathrm{r}$ & $.508^{* * *}$ & $.278^{* * *}$ & $.451^{* * *}$ & \multirow{3}{*}{$\begin{array}{r}.343^{* * *} \\
.000 \\
427\end{array}$} & \multirow[t]{3}{*}{1} \\
\hline & $\mathrm{p}$ & .000 & .000 & .000 & & \\
\hline & $\mathrm{n}$ & 427 & 425 & 427 & & \\
\hline
\end{tabular}

SEFL_INT -self-employment intentions, ATT_1 - attitudes (indirect measurement approach), ATT_2 - attitudes (direct measurement approach), SN - subjective norm, PBC - perceived behavioral control, $\mathrm{r}$ - Pearson correlation coefficient, $\mathrm{p}$ - level of significance

*** statistically significant correlation $(\mathrm{p}<0.001)$

Table 4: Correlation between variables of intentions for self-employment and TPB constructs 
The results of the multiple regression analysis are compared in the following section, and they differ in the way attitudes are measured.

Model 1 - ATT_1

\begin{tabular}{|l|c|c|c|c|c|}
\hline Model & $\mathrm{R}$ & $\mathrm{r}^{2}$ & $\begin{array}{c}\text { Adjusted } \\
\mathrm{r}^{2}\end{array}$ & $\begin{array}{c}\text { Std. error } \\
\text { of estimate }\end{array}$ & $\begin{array}{c}\text { Durbin- } \\
\text { Watson test }\end{array}$ \\
\hline $\begin{array}{l}\text { Model 1- } \\
\text { ATT_1 }\end{array}$ & .655 & .430 & .426 & .63360 & 1.992 \\
\hline
\end{tabular}

Table 5: Results of the multiple regression model (1)

The explanation of variance based on these three independent variables (TPB) is high $\left(r^{2}=0.430\right.$, adjusted $\left.r^{2}=0.426\right)$. Since the F-ratio is statistically significant $(\mathrm{p}<0.001)$, the coefficient of determination is also considered significant. Autocorrelation is not present in the analyzed variables (Durbin-Watson test $=$ 1.992), nor do the indicators of multicollinearity exceed the allowed values, and all the variables in the model are considered valid. Regression coefficients, indicating the importance of individual variables in the regression model, were calculated for each independent variable (Table 6).

\begin{tabular}{|c|c|c|c|c|c|c|}
\hline \multirow{2}{*}{\multicolumn{2}{|c|}{ Model }} & \multicolumn{2}{|c|}{$\begin{array}{c}\text { Non- } \\
\text { standardized } \\
\text { coefficients }\end{array}$} & \multirow{2}{*}{\begin{tabular}{|c|}
$\begin{array}{c}\text { Standardized } \\
\text { coefficient }\end{array}$ \\
Beta \\
\end{tabular}} & \multirow[t]{2}{*}{$\mathrm{t}$} & \multirow[t]{2}{*}{ Sig. } \\
\hline & & B & $\begin{array}{c}\text { Standard } \\
\text { error }\end{array}$ & & & \\
\hline \multirow{4}{*}{$\begin{array}{l}\text { Model } 1 \text { - } \\
\text { ATT_1 }\end{array}$} & (constant) & -1.398 & . 144 & & 9.738 & $.000^{* * *}$ \\
\hline & ATT_1 & .229 & .057 & .155 & 4.007 & $.000^{* * *}$ \\
\hline & SN & .092 & .009 & .387 & 9.784 & $.000^{* * *}$ \\
\hline & PBC & .383 & .046 & .333 & 8.296 & $.000^{* * *}$ \\
\hline
\end{tabular}

*** statistically significant predictor $(\mathrm{p}<0.001)$

Table 6: Coefficients of the multiple regression model (1)

The impact of all variables of the TPB on the regression model is statistically significant $(\mathrm{p}<0.001)$. Observing the impact of each of the independent variables of this model shows that subjective norm (0.387) has the greatest impact, followed by perceived behavioral control (0.333), and attitudes (0.155). These results open the discussion on the $\mathrm{H} 1$ hypothesis. 


\section{Model 2-ATT_2}

The explanation of variance on the basis of this approach for measuring attitudes towards self-employment is extremely high $\left(\mathrm{r}^{2}=0.604\right.$, adjusted $\left.\mathrm{r}^{2}=0.601\right)$. The F-ratio is statistically significant $(\mathrm{p}<0.001)$, and the assumptions of autocorrelation (Durbin-Watson test $=2.018$ ) and multicollinearity are not disrupted in the analyzed variables, and all the variables in the model are considered to be appropriate for further use in the regression model.

\begin{tabular}{|l|c|c|r|r|r|}
\hline Model & $\mathrm{R}$ & $\mathrm{r}^{2}$ & $\begin{array}{c}\text { Adjusted } \\
\mathrm{r}^{2}\end{array}$ & $\begin{array}{c}\text { Std. error } \\
\text { of estimate }\end{array}$ & $\begin{array}{c}\text { Durbin- } \\
\text { Watson test }\end{array}$ \\
\hline Model 2-ATT_2 & .777 & .604 & .601 & .63360 & 2.018 \\
\hline
\end{tabular}

Table 7: Results of the multiple regression model (2)

When observing the impact of each of the independent variables of the second model, it becomes evident that self-employment intentions are impacted the most by attitudes (0.560), followed by perceived behavioral control (0.197), and subjective norm (0.169).

\begin{tabular}{|c|c|c|c|c|c|c|}
\hline \multirow{2}{*}{\multicolumn{2}{|c|}{ Model }} & \multicolumn{2}{|c|}{$\begin{array}{c}\text { Non- } \\
\text { standardized } \\
\text { coefficients }\end{array}$} & \multirow{2}{*}{$\begin{array}{c}\begin{array}{c}\text { Standardized } \\
\text { coefficient }\end{array} \\
\text { Beta }\end{array}$} & \multirow[t]{2}{*}{$\mathrm{t}$} & \multirow[t]{2}{*}{ Sig. } \\
\hline & & B & $\begin{array}{c}\text { Standard } \\
\text { error }\end{array}$ & & & \\
\hline \multirow{4}{*}{$\begin{array}{l}\text { Model } 2- \\
\text { ATT__2 }^{2}\end{array}$} & (constant) & -2.568 & .143 & & $17.918^{-}$ & $.000 * * *$ \\
\hline & ATT_2 & .556 & .038 & .560 & 14.630 & $.000 * * *$ \\
\hline & $\mathrm{SN}$ & .040 & .009 & .169 & 4.647 & $.000^{* * *}$ \\
\hline & PBC & .226 & .040 & .197 & 5.680 & $.000 * * *$ \\
\hline
\end{tabular}

*** statistically significant predictor $(\mathrm{p}<0.001)$

Table 8: Coefficients of the multiple regression model (2)

When comparing the results of Model 1 and Model 2, which differ in the way attitudes are measured (Table 9), it becomes evident that the second model provides a more significant explanation of variance compared to the first model.

\begin{tabular}{|l|c|r|}
\hline & $\mathrm{r}^{2}$ & Adjusted $\mathrm{r}^{2}$ \\
\hline Model 1 & .430 & .426 \\
\hline Model 2 & .604 & .601 \\
\hline
\end{tabular}

Table 9: Comparison of predictive power of the models 
Both analyzed models show good exploratory strength of the theory of planned behavior $\left(\mathrm{r}^{2}{ }_{1}=0,426\right.$ and $\left.\mathrm{r}^{2}{ }_{2}=0,601\right)$, which even without interaction of other potential independent variables provide a significant predictive role in explaining self-employment intentions. However, if the models (approaches to measurement) are compared, it becomes evident that both models do not indicate equal importance of predictor variables. According to the set hypothesis H1, it is expected that intentions towards self-employment will keep the greatest predictive ability of the model in both cases, regardless of how they are measured. The results do not provide sufficient evidence for non-rejection of H1, therefore this hypothesis is rejected, since according to Model 1 (indirect method of measurement) attitudes have the lowest predictive ability compared to the other two elements of the TPB, while in Model 2 (direct method of measurement) attitudes are isolated as the predictor with the greatest impact on the dependent variable.

However, the most important difference between the models is apparent in the percentage of interpretation of models (Model 1: adjusted $\mathrm{r}^{2}=0.426$; Model 2: adjusted $\left.\mathrm{r}^{2}=0.601\right)$. Consequently, it is evident that the second approach in measuring attitudes is more suitable for researching self-employment intentions, and therefore hypothesis $\mathrm{H} 2$ is not rejected, according to which choosing a different approach in measurement of attitudes towards self-employment has significant predictive ability in explain self-employment intentions.

\section{Conclusion}

Completion of formal education marks a period during which young individuals need to choose a career path. This segment of population should be taken very seriously, because today's student population is important for social and economic trends. Accordingly, equal attention to research should be devoted to selecting a properly directed career and, and students, by acquiring specific knowledge and skills, should be prepared for market competition that awaits them after graduation.

The methodological contribution is useful for future researchers in terms of modelling self-employment intentions of student population as reflected in different approaches to testing the measured concept. The results of this research confirm a higher correlation and greater explanation of variance in the multiple regression model when the measured construct is measured using an aggregate variable, as compared to the Kolvereid's approach, which consisted of 11 factors. Theoretically, further research should focus on investigation of self-employment intentions of students enrolled in non-business university programs as well as in specific programs at polytechnics. It will be interesting to compare university students and students attending professional studies where curricula are oriented 
towards acquiring practical knowledge during studies. Further research of selfemployment intentions in Croatia should include longitudinal series of data and tracking of students after their studies and in employment, and even when changing their careers. The analyzed models provide concrete insights into the strength of the impact of certain predictors on selecting self-employment as a career, but it remains to be seen whether students with strong self-employment intensions have indeed achieved such goals. If not, hindrances and obstacles to such goals should be determined. From a methodology standpoint, modelling intentions requires a methodological shift where the application of qualitative techniques have a significant role.

\section{References}

[1] Ajzen, I. (1991). The theory of planned behavior. Organizational behavior and human decision processes, 50(2), 179-211.

DOI: 10.1016/0749-5978(91)90020-T.

[2] Ajzen, I. (2001). Nature and operation of attitudes. Annual review of psychology, 52(1), 27-58. DOI: 10.1146/annurev.psych.52.1.27.

[3] Audet, J. (2004). A longitudinal study of the entrepreneurial intentions of university students. Academy of Entrepreneurship Journal, 10(1-2), 3-16.

[4] Autio, E., Keeley, R. H., Klofsten, M., Parker, G. G. C. and Hay, M. (2001). Entrepreneurial Intent among Students in Scandinavia and in the USA. Enterprise and Innovation Management Studies, 2(2), 145-160. Available at: http://dx.doi.org/10.1080/14632440110094632.

[5] Autio, E., Keeley, R. H., Klofsten. M and Ulfstedt, T. (1997). Entrepreneurial intent among students: testing an intent model in Asia, Scandinavia and USA. Boston: Babston College.

[6] Bagozzi, R. and Yi, Y. (1989). An investigation into the role of intentions as mediators of the attitude behavior relationship. Journal of Economic Psychology, 10(1), 35-62. DOI:10.1016/0167-4870(89)90056-1.

[7] Basu, A. and Virick, M. (2008). Assessing entrepreneurial intentions amongst students: a comparative study. In 12th Annual Meeting of the National Collegiate Inventors and Innovators Alliance (pp.79-86). Dallas, USA: San Jose State University.

[8] Bird, B. (1988). Implementing entrepreneurial ideas: The case for intentions. Academy of Management Review, 13(3), 442-454.

DOI: 10.5465/AMR.1988.4306970.

[9] Carsrud, A., Gaglio, C. and Kernochan, R. (1993). Demographics in entrepreneurship research: Guidelines for the use of demographic data. In Katz, J. A, and Brockhaus, R. H. S. (Eds), Advances in entrepreneurship, firm emergence and growth. Greenwich, CT: JAI Press. 
[10] Fishbein, M. and Ajzen, I. (1975). Belief, attitude, intention and behavior: An introduction to theory and research. New York: Addison-Wesley.

[11] Gird, A. and Bagraim, J. J. (2008). The theory of planned behaviour as predictor of entrepreneurial intent amongst final-year university students. South African Journal of Psychology, 38(4), 711-724.

DOI: $10.1177 / 008124630803800410$.

[12] Helmreich, R. L. and Spence, J. T. (1978). The Work and Family Orientation Questionnaire: An objective instrument to assess components of achievement motivation and attitudes toward family and career. JSAS Catalog of Selected Documents in Psychology, 8(2), 35-62.

[13] Jaén, I., Moriano, J. A. and Liñán, F. (2010). Personal values and entrepreneurial intention: an empirical study. In Fayolle, A., Kyrö, P., Mets, T. and Venesaar, U. (Eds.). Conceptual Richness and Methodological Diversity in Entrepreneurship Research (pp. 15-31). Massachusetts: Edward Elgar Pub.

[14] Katz, J. and Gartner, W. B. (1988). Properties of emerging organizations. Academy of management review, 13(3), 429-441.

DOI: 10.5465/AMR.1988.4306967.

[15] Kolvereid, L. (1996a). Organisational employment versus self-employment: reasons for career choice intentions. Entrepreneurship Theory and Practice, 20(3), 23-31.

[16] Kolvereid, L. (1996b). Prediction of employment status choice intentions. Entrepreneurship Theory and Practice, 21(1), 47-57.

[17] Kolvereid, L. and Isaksen, E. (2006). New business start-up and subsequent entry into self-employment. Journal of Business Venturing, 21(6), 866-885. http://dx.doi.org/10.1016/j.jbusvent.2005.06.008.

[18] Krueger Jr, N. F., Reilly, M. D. and Carsrud, A. L. (2000). Competing models of entrepreneurial intentions. Journal of business venturing, 15(5), 411-432. http://dx.doi.org/10.1016/S0883-9026(98)00033-0.

[19] Krueger, N. and Brazeal, D. (1994). Entrepreneurial potential and potential entrepreneurs. Entrepreneurship Theory and Practice, 18(3), 91-105.

[20] Krueger, N. F. and Carsrud, A. L. (1993). Entrepreneurial Intentions: Applying the theory of planned behaviour. Entrepreneurship and Regional Development, 5(4), 315-330. Available at: http://dx.doi.org/10.1080/ 08985629300000020.

[21] Kuehn, K. W. and Smith, F. (2008). Entrepreneurial intentions research: Implications for entrepreneurship education. Journal of Entrepreneurship Education, 11(1), 87-98.

[22] Leffel, A. (2008). Prediction of employment status choice: An analytical approach on the relation between an entrepreneurship class at a us university and employment status intentions. In USASBE Conference Proceedings (pp. 401-417). San Antonio, Texas: The University of Texas at San Antonio. 
[23] Liñán, F. (2004). Intention-based models of entrepreneurship education. Piccolla Impresa/Small Business, 3(1), 11-35.

[24]Liñán, F. and Chen, Y. W. (2009). Development and Cross-Cultural Application of a Specific Instrument to Measure Entrepreneurial Intentions. Entrepreneurship Theory and Practice, 33(3), 593-617.

DOI: $10.1111 /$ j.1540-6520.2009.00318.x.

[25] MacMillan, I. C. and Katz, J. A. (1992). Idiosyncratic milieus of entrepreneurial research: The need for comprehensive theories. Journal of Business Venturing, 7(1), 1-8.

[26] Solesvik, M. (2011). Attitudes Towards Future Career Choice. In The 56 Annual International Council for Small Business World Conference, Back to the Future Changes in Perspectives of Global Entrepreneurship and Innovation. Norway: Haugesund University College Bjørnosngate.

[27] Solesvik, M., Westhead, P., Kolvereid, L. and Matlay, H. (2012). Student intentions to become self-employed: the Ukrainian context. Journal of Small Business and Enterprise Development, 19(1), 441-460. Available at: http://dx.doi.org/10.1108/14626001211250153.

[28] Souitaris, V., Zerbinati, S. and Al-Laham Andreas. (2007). Do entrepreneurship programmes raise entrepreneurial intenion of science and engineering students? The effect of learning, inspiration and resources. Journal of Business Venturing, 22(4), 566-591. Available at: http://dx.doi.org/ 10.1016/j.jbusvent.2006.05.002.

[29] Tkachev, A. and Kolvereid, L. (1999). Self-employment intentions among Russian students. Entrepreneurship \& Regional Development, 11(3), 269-280. Available at: http://dx.doi.org/10.1080/089856299283209.

[30] Wu, S. and $\mathrm{Wu}, \mathrm{L}$. (2008). The impact of higher education on entrepreneurial intentions of university students in China. Journal of Small Business and Enterprise Development, 15(4), 752-774. Available at: http://dx.doi.org/ $10.1108 / 14626000810917843$.

[31]Zhao, H., Seibert, S. E. and Hills, G. E. (2005). The mediating role of selfefficacy in the development of entrepreneurial intentions. Journal of Applied Psychology 90, br. 6: 1265-1272. Available at: http://dx.doi.org/10.1037/ 0021-9010.90.6.1265. 